\title{
Carbon balance of sandy loam soils in arid landscapes of the Chechen Republic
}

\author{
Rustam Gakaev* \\ Chechen State University named after A.A.Kadyrov, Grozny, Russia
}

\begin{abstract}
The spatial variability of the stability of soil aggregates and its relationship with runoff and soil erosion were studied in a semi-arid environment in the field in order to assess the validity of the stability of structures as an indicator of soil erosion in soils of sandy loam ridges. The influence of soil and relief properties on the variability of aggregate stability was also investigated. Significant relationships were found in the number of water droplets required to break down the aggregate, as well as the rate of runoff and erosion. The most significant correlation was found between the number of droplet impacts and the soil organic matter content. The stability of aggregates in the upper soil layer is apparently a valuable indicator of field runoff and inter-season soil erosion of sandy loamy ridges in semi-arid conditions.
\end{abstract}

\section{Introduction}

The mountainous landscapes of the region represent the northern slope of the Main Caucasian ridge with its continuous orographic network. Various parent rocks of extremely rugged relief, a variety of mountain heights, the shape and direction of ridges, and various climatic conditions determine the presence of various soil varieties and vegetation formations in the mountains [1]. Mountains characterize a variety of parent rocks, which significantly influence the soil-forming process. On granites, for example, they form, poor in nutrients, acidic; nearby, on limestones with a slightly alkaline reaction - humus, darkcolored soils, rich in nutrients. On clay shales with different chemical composition, loamy multi-colored soils of a certain chemical composition are formed. The concentration of carbon dioxide in the atmosphere has increased from about 280 ppmv to about $405 \mathrm{ppmv}$ today due to the burning of fossil carbon (coal and oil). The question of how to stop or reduce the increase in the concentration of $\mathrm{CO} 2$ in the atmosphere is currently being studied. One possibility is to use photosynthesis to release atmospheric $\mathrm{CO} 2$ as aboveground biomass carbon (ABC) and in roots. Thus, since 2003, almost 4 billion tons of ABC have been stored in the Chechen Republic from tree planting, which is $25 \%$ of its annual emissions from fossil fuels. Trees, which have a limited lifespan, are temporary stores of carbon for centuries only. In temperate climates, afforestation can compete with agriculture, resulting in reduced food production. It investigates a proposal to capture atmospheric carbon dioxide through afforestation in semi-arid regions as inorganic soil carbonate below

\footnotetext{
*Corresponding author: rustam.geofak@yandex.ru
} 
the earth's surface in the unsaturated zone (USZ) [3]. In semi-arid regions, there is marginal agriculture, but the local flora (trees and shrubs with deep roots) can be supported by 250 $600 \mathrm{~mm}$ of annual rainfall. In semi-arid regions, the unsaturation zone (USZ), which extends from the land surface down to the water table, is quite thick. Whereas in temperate regions, coniferous and deciduous forests take about $2.8 \mathrm{~m}$ deep rooting, in drier areas the plants sink their roots much deeper to reach the water. For example, the roots of the shepherd dog (Boscia albitrunca) and acacia tree can exceed $60 \mathrm{~m}$, while the Israeli tamarisk (Tamarix aphylla) can sink $20 \mathrm{~m}$ [5]. Long-term storage of inorganic carbon below the earth's surface has generally been neglected. $\mathrm{CO} 2$ released through roots, combined with bacterial oxidation of soil organic matter, can create a partial pressure of $\mathrm{CO} 2$ in the soil several orders of magnitude higher than in the overlying ambient atmosphere. Some of this gas diffuses upward and leaves the soil. The rest can interact with soil moisture: high partial pressure of $\mathrm{CO} 2$ forms dissolved inorganic carbon (DIC), which later combines with divalent cations and precipitates as soil carbonate within the USZ [4]. With heavy precipitation, this precipitate dissolves. In semi-arid regions with sparse rainfall, precipitated calcite (soil carbonate) can remain stable for thousands of years. The pedogenic carbonate formed at the USZ and bicarbonate (DIC) together contain sequestered inorganic carbon.

\section{Calculation of the carbon balance of soil ecosystems}

Mountain meadows within the Chechen Republic, as noted above, are represented by subalpine and alpine meadows, which differ from each other in the species composition of vegetation, and, accordingly, in the reserves of phytomass and productivity. The harsh conditions of the alpine belt noticeably affect the vegetation. Low-growing alpine meadows prevail here. The height of the herbage does not exceed 10-15 cm. Large bright flowers of alpine species (bell, violet, gentian, etc.) significantly exceed the size of the leaves. The grass seems to be made up of only flowers. Thanks to this, low-growing high-mountain meadows, the basis of which is forbs, received a figurative expression - alpine carpets [6].

Soils are a significant sink of organic and inorganic carbon, which have not received adequate attention. Monger presents several compelling reasons for this claim. First of all, he believes that for soil carbonate to be a pure scavenger, calcium ions must come from silicate weathering or some other non-carbonate source. Moreover, he notes that it is technically difficult to easily determine the ratio of lithogenic to soil carbonates in soil. Soil inorganic carbon can be of two main sources, differing in their ability to extract and store

$$
\mathrm{CO}_{2}+\mathrm{H}_{2} \mathrm{O} \rightarrow \mathrm{H}_{2} \mathrm{CO}_{3} \rightarrow \mathrm{H}^{+}+\mathrm{HCO}_{3}^{-}
$$

atmospheric carbon. Lithogenic carbonates, primarily marine limestone, were formed in the distant past and have nothing to do with the modern atmosphere. Pedogenic carbonate is authigenic and forms in the soil profile when dissolved inorganic carbon (DIC) combines with calcium cations in soil moisture and eventually precipitates. Trees and shrubs breathe in atmospheric carbon dioxide for photosynthesis and breathe out some of it through the roots into the unsaturated soil zone. The partial pressure of $\mathrm{CO} 2$ in soil gas is much higher than in the surrounding atmosphere. A number of fractionation steps affect the carbon isotope ratios through different steps that start with the expiration of the $\mathrm{C} 3$ plants that are prevalent in the study areas and convert $\mathrm{CO} 2(\mathrm{~g})$ to solid carbonate sediment. Here calcium will mean all other cations (such as iron and magnesium) that carbonate minerals can form. It should be noted that although the isotopic difference between precipitation and the atmosphere is insignificant for $13 \mathrm{C}$ (about $1 \%$ ), for radiocarbon it is $100 \%$. The enclosing sediments do not initially contain $14 \mathrm{C}$, which forms in the upper atmosphere. Chemical equations of the soil dissolution process. 
Gas into soil moisture, the formation of carbon dioxide and the precipitation of calcite can be represented in a simplified form as:

Soil $\mathrm{CO} 2$ combines with soil moisture to form a carbonic acid solution that rapidly dissociates into $\mathrm{H}+$ and $\mathrm{HCO} 3$. In this reaction, atmospheric $\mathrm{CO} 2$ becomes bicarbonate

$$
\mathrm{CaCO}_{3}+\mathrm{H}^{*}-\mathrm{Ca}^{2 *}+\mathrm{HCO}_{3}^{-}
$$

(DIC), usually the most abundant groundwater anion.

$$
\mathrm{Ca}^{2+}+2 \mathrm{HCO}_{3}{ }^{-} \rightarrow \mathrm{CaCO}_{3 \downarrow}+\mathrm{CO}_{2 \uparrow}+\mathrm{H}_{2} \mathrm{O}
$$

The dissolution reaction is comparable to carbon sequestration since atmospheric $\mathrm{CO} 2$ is the source. Carbonic acid formed in the formula. (1), can dissolve existing calcite (mainly limestone) in the soil with the release of calcium ions. HCO3 is in the equation. (2) comes from relict carbonate not associated with modern atmospheric $\mathrm{CO} 2$. Therefore, this $\mathrm{HCO} 3$ does not capture modern atmospheric $\mathrm{CO} 2$.

$$
2 \mathrm{CO}_{2}+3 \mathrm{H}_{2} \mathrm{O}+\mathrm{CaSiO}_{3} \rightarrow \mathrm{H}_{4} \mathrm{SiO}_{4}+2 \mathrm{HCO}_{3}^{-}+\mathrm{Ca}^{2+}
$$

The cations are released in the equation. (2) combine with ICE. Through various processes, mainly $\mathrm{CO} 2$ degassing or $\mathrm{H} 2 \mathrm{O}$ evaporation, secondary calcite is precipitated. Factors limiting the rate of secondary carbonate formation include $\mathrm{Ca} 2+$ content and $\mathrm{CO} 2$ partial pressure. However, the equation. (3) would mean that atmospheric $\mathrm{CO} 2$ is not captured if for every mole of calcite formed, 1 mole of $\mathrm{CO} 2$ is returned to the atmosphere. Thus, it was assumed that the formation of soil carbonate is neutral from the point of view of carbon capture and storage in the atmosphere. However, when this reaction occurs in the USZ soil column, which is usually thick in semi-arid regions, only the topmost fraction is in direct contact with the atmosphere. While this can be viewed as an "open system", the rate of gas evolution is diffusion limited. Most of the $\mathrm{CO} 2$ emitted by the formula. (3), especially due to precipitation at depth, ingress and mixing with $\mathrm{CO} 2$ with a relatively high partial pressure in the USZ soil gas should be expected. In the presence of non-carbonate sources of calcium ions, there will be a net binding of $\mathrm{CO} 2$ from the atmosphere. Wollastonite is used here as a typical calcium silicate mineral for purposes of illustration in equation (4).

With the weathering of silicates, all $\mathrm{CO} 2$, in contrast to carbonate weathering, is ultimately formed from atmospheric $\mathrm{CO} 2$. In this way, a net sequestration of atmospheric $\mathrm{CO} 2$ is unambiguously occurring. In nature, there are a variety of sources of calcium ions, in addition to silicate weathering or from relict limestone. Moreover, if the sediment contains other sources of calcium, which can adsorb as a cation on the surface of mixed clay minerals, weathering of feldspar or gypsum, sea spray or rain, then when $\mathrm{Ca} 2+$ combines, net binding of atmospheric $\mathrm{CO} 2$ can occur. with $\mathrm{HCO} 3$ - (equation (1)) for the precipitation of calcite. Therefore, it is important to evaluate sequestration in the field rather than in a theoretical or laboratory setting.

\section{Results and Discussions}

In the process of photosynthesis, plants absorb carbon and return some of it to the atmosphere through respiration. The carbon that remains in plant tissue is then consumed by animals or added to the soil as bedding when the plants die and decay. The main storage method for carbon in soil is soil organic matter (SOM). SOM is a complex mixture of carbon compounds, consisting of decaying plant and animal tissues, microbes (protozoa, nematodes, fungi and bacteria) and carbon bound to soil minerals. Carbon can be stored in 
the soil for thousands of years, or it can be quickly released back into the atmosphere. Climatic conditions, natural vegetation, soil structure and drainage all affect the amount and duration of carbon storage. The main sources of the mountain agricultural potential of the North-Eastern Caucasus are the presence in the mountains of 64.5 thousand hectares of arable land, 227.3 thousand hectares of pastures, 41.2 thousand hectares of hayfields, as well as 279.3 thousand hectares of mountain forests with an abundance of wild fruits and berries [11]. However, these huge reserves of agricultural and livestock production are underutilized and developed extremely slowly. For more than 40 post-war years, we have not reached the level of 1940 in terms of the population in the mountains, the availability of arable land and livestock there. Consider in more detail the potential of these reserves and the main ways of using them.

Potential mountain, arable land. As already noted, in the mountains of the region in 1940, 64.5 thousand hectares of arable land were cultivated (together with the household plots of the population), of which about 22 thousand hectares were collective farms. In 1987, the sown area here amounted to 16.4 thousand hectares, including 12.8 thousand hectares in collective farms and 3.6 thousand hectares in the individual sector. Thus, currently 48.1 thousand hectares of arable land are not used in the mountains. This is a considerable reserve for agricultural production [9]. Taking into account the high-rise location of mountain arable lands, according to preliminary calculations, in the future, with the full development of the mountains, the following amount of food products and fodder can be grown here annually. On the 64.5 thousand hectares of arable land available in the mountains, it is possible to produce annually: 43.6 thousand tons of grain and leguminous crops, 66 thousand tons of potatoes, 2.2 thousand tons of oil flax, 3.4 thousand tons of tobacco, 46.2 thousand tons of main and secondary feeds. In addition, on a mountain arable land without large costs, it is possible to lay in the order of the first stage orchards on an area of 10 thousand hectares and nut-bearing 1 thousand hectares. Forage resources in the mountains allow you to keep in the summer: 20 thousand cows, 100 thousand heads of young large stingray, 150 thousand sheep and 6837 horses: in winter: 19.8 thousand heads of young cattle, 100 thousand sheep and 6837 horses [10].

Land cover changes in arid regions are often associated with the displacement of herbaceous life forms by arboreal ones. This shift in vegetation is often a response to extensive grazing.

\section{Conclusions}

As the forest grows, carbon accumulates in woody tissues and soil organic matter. The net carbon sequestration rate is highest when forests are young, but declines over time. Old forests can capture carbon for a long time, but provide little or no net absorption. When a forest is cleared, the carbon it contains can quickly return to the atmosphere if the wood tissue is burned or converted into short-lived products such as paper. If wood is used for construction or furniture, then these products store carbon throughout their life and act as carbon sinks. A post-harvest approach that reduces waste and converts most wood into long-lived products is an effective strategy to help reduce global atmospheric carbon. However, the net carbon sink in long-lived wood products is still relatively small, so deforestation ultimately contributes to reducing the accumulation of carbon on land. In agricultural systems, the amount and duration of carbon storage is largely determined by how soil resources are managed. Many farming methods have been proposed that can improve carbon storage. Management decisions need to consider the benefits of these various practices, as well as their potential hidden costs. While not discussed here, there may also be direct or indirect monetary costs and benefits for farmers from adopting these methods. Benefits of soil carbon sequestration Removing $\mathrm{CO} 2$ from the atmosphere is only 
one of the significant benefits of improved soil carbon storage. Improved soil and water quality, reduced nutrient loss, reduced soil erosion, increased water savings, and increased yields can result from increased carbon stored in agricultural soils. Management practices that ensure net carbon sinks in soils include the following [12]:

- Conservation tillage minimizes or eliminates manipulation of the soil for growing crops. It includes mulch tillage, in which plant residues remain on the soil surface. These treatments usually reduce soil erosion, improve water-use efficiency, and increase the concentration of carbon in the topsoil. Conservative tillage can also reduce the amount of fossil fuels used by agricultural businesses. It has been calculated that it can capture significant amounts of $\mathrm{CO} 2$.

- Cover cropping is the use of crops such as clover and small grains to protect and improve the soil between regular cropping periods. Cover crops improve carbon sequestration by improving soil structure and adding organic matter.

- A crop rotation is a sequence of crops grown in a regularly repeated sequence on the same area of land. This mimics the diversity of natural ecosystems more accurately than intensive monoculture farming methods. Changing the type of crops grown can increase the level of organic matter in the soil. However, the efficiency of the crop rotation depends on the type of crops and the duration of the crop rotation.

On the calcareous soils of the Rocky and Pasture Ridges, which are also characterized by a lower climate humidity, short-legged forbs steppe meadows are also widespread. Tallherb grass-forb meadows are usually found in small areas on the richest soils of subalpine meadows and the upper strip of the forest belt. In the composition of their herbage, a significant proportion belongs to tall, very valuable forage grains - Georgian bluegrass and long-leaved bluegrass, hedgehog, high ryegrass, etc. [13]. Among legumes, there are meadow rank, balanza vetch, fence peas and arcuate and similar clover. Forbs are represented by hogweed, Caucasian capitate, large-flowered letter, meadow geranium, bunch of anemone, etc. The height of the herbage reaches $150 \mathrm{~cm}$, the yield of hay is $20-25$ c / ha [14].

\section{Acknowledgments}

The work was carried out within the framework of the state assignment of the Ministry of Science and Higher Education of the Russian Federation (topic No. 075-03-2021-074 / 4).

\section{References}

1. A. I. Utkin, D. G. Zamolodchikov, O. V. Honest, Pools of phytomass carbon, biological carbon and soil nitrogen in the forest fund of Russia, 18-34 (2019)

2. A. M. Tarko, Mathematical modeling, 231(2019)

3. R. A. Gakaev, Comprehensive assessment of the current state of the mountain-forest landscapes of the Chechen Republic and measures for their optimization, 189-194 (2008)

4. R. A. Gakaev, I. A. Bayrakov, M. I. Bagasheva, Environmental problems. Looking into the future, 50-52 (2020)

5. A. M. Vladimirov, F. A. Imanov, Principles for assessing the ecological flow of rivers, 225-229 (2019)

6. Ya. P. Molchanova, Hydrochemical indicators of the state of the environment, 192 (2019) 
7. N. I. Egorova, O. I. Mityakova, Environmental Innovation and Sustainable Development, 209-215 (2020)

8. P. P. Tans, D. W. R. Wallace, Change and Pedogenic Carbonates, 257-272 (2018)

9. R. T. Watson, I. R. Nobel, Land Use, Land-use Change, and Forestry, p. 236 (2018)

10. J. Meckling, L. Hughes, New Political Economy, 88-104 (2020)

11. K. A. Hibbard, S. Archer, D. S. Schimel, D. W. Valentine, Ecology, 82 (2019)

12. H. C. Monger, Soils as generators and sinks of inorganic carbon in geologic time, $27-$ 36 (2020)

13. J. Meckling, L. Hughes, New Political Economy, 88-104 (2019)

14. I. Monasterolo, M. Raberto, Ecological Economics, 228-243 (2020) 